\title{
Progression of powdery mildew on different varieties of wheat and triticale in relation to environmental conditions
}

\author{
VIPIN KUMAR SHARMA ${ }^{1 *}$, RAM NIWAS ${ }^{1}$, S.S. KARWASRA ${ }^{1}$ and M.S. SAHARAN ${ }^{2}$ \\ ${ }^{1}$ Department of Plant Pathology, CCS Haryana Agricultural University, Hisar-125004, India \\ ${ }^{2}$ Indian Institute of Wheat \& Barley Research (IIWBR), Karnal-132001, India \\ *mr.vipinsharma007@gmail.com
}

\begin{abstract}
Six varieties of wheat and triticale (DDK1029, TL2934, PBW174, DPW 621-50, PBW343 and PBW590) were sown in the field of Indian Institute of Wheat and Barley Research, Karnal, Haryana (IIWBR) and Regional Research Station, Dhaulakuan under Himachal Pradesh Krishi Vishvavidyalaya, H.P during seasons 2012-13 and 2013-14 to study the role of environmental factors on the development of powdery mildew of wheat (Erysiphe graminis f.sp. tritici). The disease development was positively correlated with temperatures and negatively correlated with evening relative humidity and rainfall under field conditions. Best fit regression model was developed with maximum temperature, evening relative humidity and rainfall across the varieties and locations which explains $64 \%$ variation in powdery mildew disease.
\end{abstract}

Key words: Wheat, Triticale, Erysiphe graminis f.sp. tritici, epidemiology, weather parameter

Powdery mildew is one of the widely destructive plant disease in the world. Powdery mildew is caused by biotrophic parasitic fungus Erysiphe graminis f.sp. tritici Em. Marchal (syn: Blumeria graminis), with well developed haustoria that permit it to feed on the cell contents without extensive injury to the supporting tissue. Powdery mildew was endemic in foot hills and valley areas of northen and southern hills in India. However due to changing cropping practices, it has become an important disease in warmer regions and plains also (Bahadur et al., 1996). It is observed to be severe in northen India especially in Punjab on widely grown wheat varieties PBW 343, WH 542, UP 2338 etc. Rani and Munshi (2004) reported that disease index was positively and significantly correlated with temperature, whereas humidity was not a pre-requisite for disease development. In view of the enormous losses caused by this disease, different environmental factors affecting epidemic development of the disease under field conditions were studied.

\section{MATERIALS AND METHODS}

Wheat and triticale varieties DDK1029 and TL2934 powdery mildew resistant, PBW174 and DPW 621-50 moderately resistant, PBW343 and PBW590 susceptible were sown in the field of Indian Institute of Wheat and Barley Research, Karnal, Haryana (IIWBR) and Regional Research Station, Dhaulakuanunder Himachal Pradesh Krishi Vishvavidyalaya, H.P, with three replications. The observations on disease intensity for each variety, ten leaves were marked randomly, and powdery mildew growth was measured regularly till the senescence or drying of leaves on different varieties at 5 days interval. The disease reaction was recorded based on scale given by Saari and Prescott (1975). The data on environmental variables viz. maximum and minimum temperature, morning and evening relative humidity, rainfall and sunshine hours were obtained from meteorology laboratories of IIWBR, Karnal and Regional Research Station Dhaulakuan, Himachal Pradesh. Per cent disease index (PDI) was calculated by formula given by Wilcoxson et al. (1975):

$\mathrm{PDI}=\frac{\text { Total sum of numeral rating }}{\text { Total number of plants observed X Maximum disease grade }} \mathrm{X} 100$ Correlation was carried out between weather parameters and percent disease intensity by pooling the data of all the varieties and both locations during the season 2012-13. Multiple regression equation was developed for estimation disease intensity based on significant weather parameters of the year 2012-13 using stepwise regression analysis. This multiple regression equation was used for prediction of disease intensity using weather as input parameters at both the locations during the season 2013-14. Goodness of fit between actual and estimated/predicted percent disease index were tested using Chi square test.

\section{RESULTS AND DISCUSSION}

The powdery mildew (Erysiphe graminis f.sp. tritici) progress was measured on different wheat varieties in terms 
Karnal

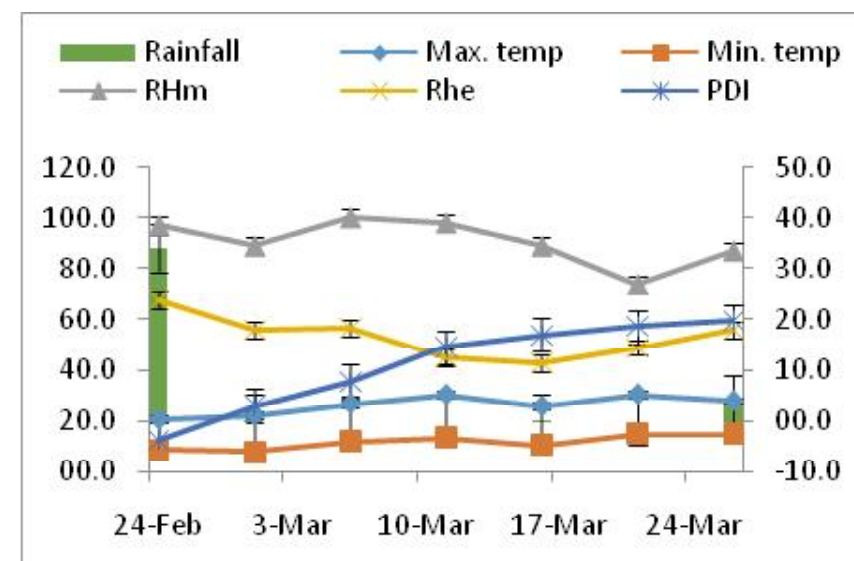

2012-13

Dhuala Kuan

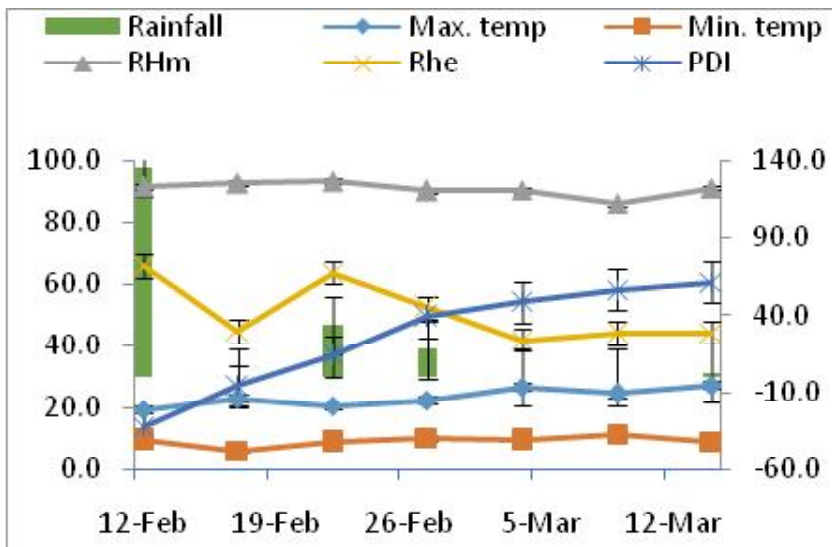

2013-14

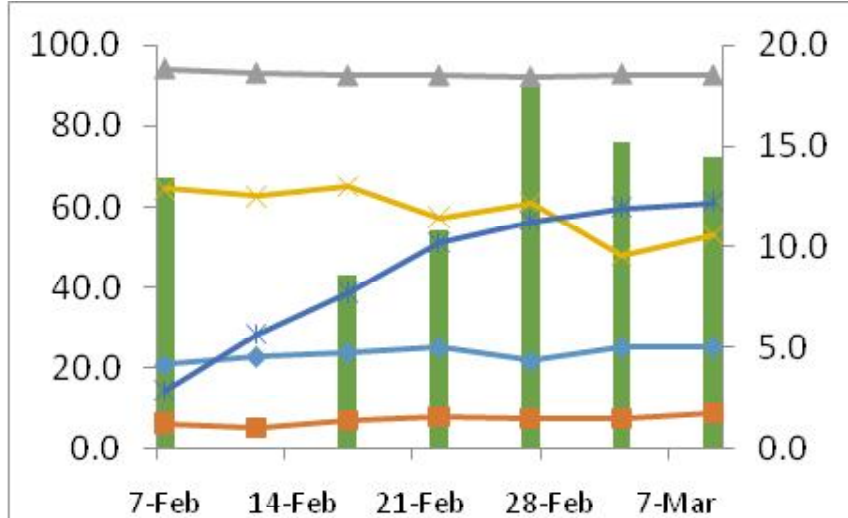

Fig 1: Development of powdery mildew (Erisiphe gramminis f.sp. tritici) on wheat cultivar PBW 343 at Karnal and Dhaulakuan during 2012-13 and 2013-14

of per cent disease index in relation with prevailing weather conditions. Powdery mildew was observed on all the variety in third week of February except cultivar DDK 1029 and TL 2934, which were infected in last week of February in Karnal. The temporal variation in per cent disease index (PDI) of susceptible variety (PBW 343) is depicted in Fig. 1 along with weather parameters of both seasons and locations. Powdery mildew infected wheat crop later during $1^{\text {st }}$ season as compared to second season. Similarly incidence on wheat crop was earlier at Dhaula Kuan during second season. The disease incidence was about 12 days earlier in wheat crop grown at Dhaula Kuan as compared to wheat at Karnal station during both crop seasons. Initially PDI was around 12.8 per cent and increased with linear rate up to $1^{\text {st }}$ week (2012-13) and $2^{\text {nd }}$ week (2013-14) of March thereafter comparatively at slow rate and attained maxima in last fortnight of March at Karnal. In March, rise in temperature did not favored development of the pathogen might be due to lesser availability of green tissue towards maturity. According to Mzhavanadze (1975) development of powdery mildew resistance was favoured by relatively cold weather (air temperature of 14.5 to $18.2^{\circ} \mathrm{C}$ ) and relative humidity of $50-80$ per cent. Boskovic (1988) found that severe infection of powdery mildew occurred at $12-16^{\circ} \mathrm{C}$.

The coefficients of correlation between disease index and weather parameters (Table 1) shows that coefficients were significant with maximum temperature $(\operatorname{Tmax})(\mathrm{r}=0.72)$, evening relative humidity $(\mathrm{RHe})(\mathrm{r}=-0.71)$. and rainfall $(\mathrm{r}=-0.60)$ negatively correlated with disease index. This indicates that the temperature, humidity and rainfall are important for powdery mildew disease progression. Kumar and Singh (1987) found that conidia of wheat powdery mildew germinated at temperatures between $5-30^{\circ} \mathrm{C}$ with an optimum at $20^{\circ} \mathrm{C}$ in dark and at 100 per cent relative humidity. Pandey et al., (2004) reported different climatic requirement of powdery mildew in Ber while Kanzaria et al., (2013) developed prediction model for powdery mildew in mustard in Saurashtra, Gujarat.

Multiple regression equation was developed for 

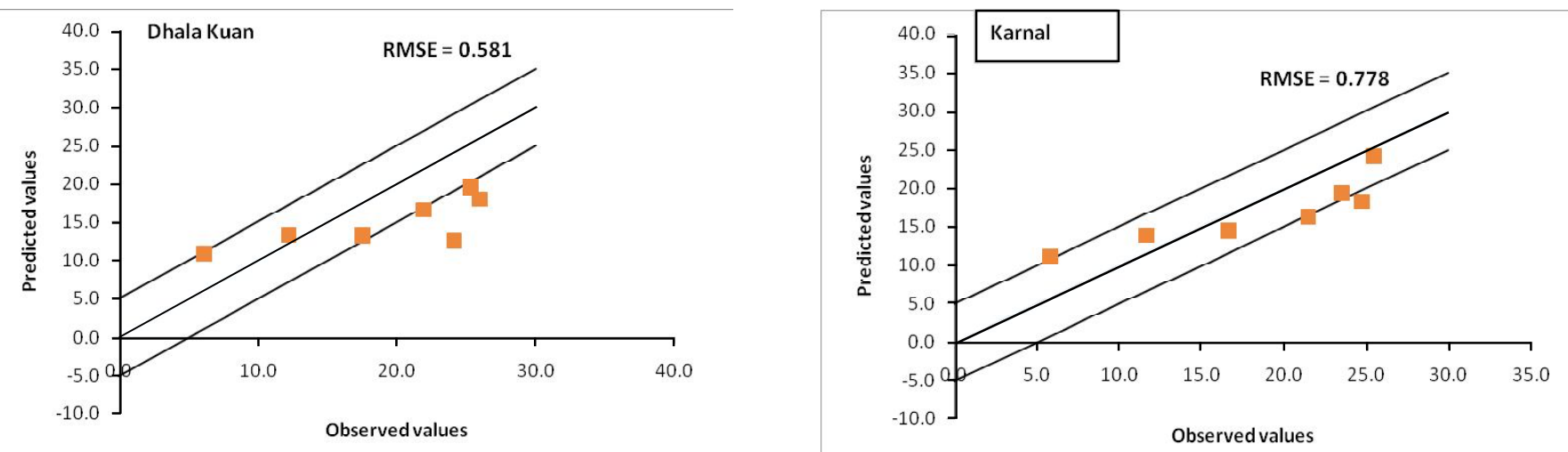

Fig 2: Comparison between observed and predicted values of powdery mildew disease on at Karnal and Dhuala Kuan

Table1: Correlation between powdery mildew disease progression on wheat and weather parameters (pooled data for all variety and locations)

\begin{tabular}{lc}
\hline Weather Parameters & Correlation Coefficient $(\mathrm{r})$ \\
\hline Maximum temperature & $0.72^{*}$ \\
Minimum temperature & 0.56 \\
Morning relative humidity & -0.44 \\
Afternoon relative humidity & $-0.71^{*}$ \\
Rainfall & $-0.60^{*}$ \\
\hline
\end{tabular}

prediction of mildew disease index in wheat across the varieties and locations for the year 2012-13.

$$
\begin{aligned}
& \mathrm{PDI}=0.838 \times \mathrm{Tmax}-0.321 \times \mathrm{RHe}-0.017 \mathrm{x} \mathrm{RF}+14.3 \\
& \text { (1.56) (1.47) } \\
& (0.32) \quad(0.69) \\
& \mathrm{R}^{2}=0.64 *
\end{aligned}
$$

Maximum temperature, evening relative humidity and rainfall collectively explained the variability in disease progression up to 64 per cent. The overall $\mathrm{R}^{2}$ value indicates that unaccounted variability of 36 per cent in disease progression was due to some unknown factors involved in the powdery mildew disease development in wheat. The present results are in accordance with the studies done by Podhradszky and Csuti (1962), that mild temperature were also reported to be favourable for disease development.

The best fit model based on three weather parameters was used for prediction of powdery mildew disease progression for the year 2013-14 at both locations. The predicted disease intensity values were compared with the observed values in wheat grown at Karnal and Dhaula Kuan stations during 2013-14 and their progression is depicted in Fig. 2. RMSE value indicates that predicted values followed observed disease intensity more closely at Dhaula Kuan as compared to Karnal.

\section{CONCLUSION}

Based on the above results it is concluded that powdery mildew disease progression was best associated with maximum temperature followed by evening relative humidity. Temperature increment favoured and relative humidity increment disfavoured the powdery mildew disease progression.

\section{REFERENCES}

Bahadur, P., Khare, C.P., Aggarwal, R., Malik, P.K. and Tiwari, G. (1996). Combined effect of powdery mildew and leaf rust in grain weight reduction of wheat cv. WL 711. Int J. Trop. Pl. Dis., 14: 59-65.

Boskovic. J.(1988). Research on the epidemiology and ecology of four spring wheat pathogens in mountaineous regions of Bosnia and Hercegovina. Zast Bilja, 39 : 323-33.

Kanzaria, K. K., Dhruj, I. U. and Sahu, D. D. (2013). Influence of weather parameters on powdery mildew disease of mustard under North Saurashtra agroclimatic zone. $J$. Agrometeorol., 15(1): 86-88.

Kumar, P. and Singh, A. (1987). Factors affecting the conidial germination in Erysiphe graminis f.sp. tritici in vitro. Indian J. Pl. Path., 5: 101-104.

Mzhavanadze, A.V. (1975). Study on factors favouring the epiphytotic development of powdery mildew of wheat. Trudy Nauchno-Issledovaters Kogo Instituta Zashchity rastenii Gruz. SSR., 27: 147-152.

Nofal, M.A., Haggag, W.M. (2006). Integrated management of mango in Egypt. Crop Protection, 25 (5), 480-486.

Pandey, V., Patel, D.S., Patel, B. M. and Patel S. I. (2004). Effect of weather variables on outbreak on spread of powdery mildew disease in Ber. J. Agrometeorol., 6 (special Issue). 124-128. 
Podhradszky, J. and Csuti, I. (1962). Wheat and barley mildew epidemics in Hungary in 1961. Novenytermeles, 11 : 249-256.

Rani, U. and Munshi, G.D. (2004). Dynamics of Erysiphe graminis $\mathrm{f}$,sp. tritici causing powdery mildew of wheat as affected by environmental factors. Pl. Dis. Res., 20 (2): $122-125$.
Saari, E.E. and Prescott, J.M. (1975). A scale for appraising the foliar intensity of wheat diseases. Pl. Dis. Reptr., 59 : 372-380.

Wilcoxson, R.D., Skoymand, B. andAtif,A.H.(1975). Evaluation of wheat cultivars for ability to retard development of stem rust. Ann. Appl. Biol., 80 : 275-281. 